\title{
Phytochemical Features of Moringa oleifera Leaves as Anticancer A Review Article
}

\author{
Ludovicus Edwinanto, Endry Septiadi, Latifah R Nurfazriah, \\ Karina S Anastasya, Natallia Pranata \\ Biomedical Sciences Master Program, Faculty of Medicine, Universitas Padjadjaran \\ Jl. Prof. Eyckman 38, Bandung 40161, West Java, Indonesia \\ Email: ludovicusedwinanto@gmail.com
}

\begin{abstract}
Cancer is a disease that can threaten human life. Various methods of cancer therapy have been widely practiced, one of which is chemotherapy. But the cost used for the therapy is also very expensive. This difficulty led many researchers to conduct research to find active compounds from natural materials. Moringa leaf (Moringa oleifera) has cytotoxic activity, because it contains a lot of flavonoids. Flavonoids are polyphenol compounds produced from secondary metabolism in plants. The most flavonoids that are anticancer active substances in the Moringa leaf are quercetin, kaempferol and myricetin. Cytotoxic activity because these active substances can induce apoptosis through intrinsic pathways by inhibition of mitogenactivated protein kinase (MAPK), extracellular-signal-regulated kinase 1/2 (ERK 1/2), c-Jun Nterminal protein kinase 1 (JNK), and protein kinase C $(P K C)$.
\end{abstract}

Keywords: Moringa leaf, quersetin; kaempferol; myricetin; anticancer 


\title{
Studi Pustaka Fitur Fitokimia Daun Kelor (Moringa oleifera) yang Memiliki Efek Antikanker
}

\author{
Ludovicus Edwinanto, Endry Septiadi, Latifah R Nurfazriah, \\ Karina S Anastasya, Natallia Pranata \\ Program Studi Magister Ilmu Kedokteran Dasar, \\ Fakultas Kedokteran, Universitas Padjadjaran \\ Jl. Prof Eyckman 38 Bandung 40161, Jawa Barat, Indonesia \\ Email: ludovicusedwinanto@gmail.com
}

\begin{abstract}
Abstrak
Kanker merupakan penyakit yang dapat mengancam kehidupan manusia, berbagai metode terapi penyakit kanker telah banyak dilakukan, salah satunya adalah kemoterapi. Akan tetapi biaya yang digunakan untuk terapi tersebut juga sangat mahal. Kesulitan ini menyebabkan banyak peneliti melakukan penelitian untuk menemukan senyawa aktif dari bahan alam. Daun kelor (Moringa oleifera) mempunyai aktivitas sitotoksik, dikarenakan daun kelor tersebut banyak mengandung flavonoid. Flavonoid merupakan senyawa polifenol yang dihasilkan dari metabolisme sekunder pada tanaman. Flavonoid terbanyak sebagai zat aktif antikanker pada daun kelor adalah kuersetin, kaempferol dan myricetin. Aktivitas sitotoksik dikarenakan zat-zat aktif ini dapat menginduksi apoptosis melalui jalur intrinsik dengan cara inhibisi mitogenactivated protein kinase (MAPK), extracellular-signal-regulated kinase 1/2 (ERK 1/2), c-Jun $N$-terminal protein kinase 1 (JNK), dan protein kinase $C$ (PKC).
\end{abstract}

Kata kunci: daun kelor; kuersetin; kaempferol; myricetin; antikanker 
Review Article

\section{Pendahuluan}

Kanker merupakan penyakit yang dapat mengancam kehidupan manusia, karena pengobatan yang efektif belum ditemukan. Berbagai metode terapi penyakit kanker telah banyak dilakukan, salah satunya adalah kemoterapi. ${ }^{1}$ Senyawa kemoterapi dapat menghambat pertumbuhan kanker melalui penghambatan proliferasi atau membunuh sel kanker tersebut. Kelemahan metode ini adalah kesulitan dalam mendesain senyawa kemoterapi yang mempunyai aktivitas antikanker tinggi dengan efek samping minimal terhadap sel normal. ${ }^{2}$

Pengobatan kanker dengan senyawa kemoterapi bersifat targeted therapy. Salah satu contohnya menggunakan bevacizumab yang merupakan suatu monoclonal antibody bekerja dengan cara menghambat angiogenesis. Jika dikombinasi, dengan ditambahkan cisplatin pada bevacizumab dapat memperpanjang angka harapan hidup penderita kanker selama 3,7 bulan dengan efek samping hipertensi grade 2 atau lebih sebesar $25 \%$ dan $2 \%$, thromboemboli grade 3 atau lebih sebesar $8 \%$ dan $1 \%$, dan gastrointestinal fistula sebesar $3 \% .^{3}$ Akan tetapi biaya yang digunakan untuk terapi tersebut sangat mahal. ${ }^{3}$ Kesulitan ini mendorong banyak peneliti melakukan penelitian untuk menemukan senyawa aktif dari bahan alam.

Moringa oleifera $L$. atau daun kelor merupakan pohon dengan daun, biji, kulit kayu, akar, getah, dan bunga yang banyak digunakan dalam pengobatan tradisional. Ekstrak daun kelor menunjukan aktivitas sitotoksik dan belum ada laporan mengenai efek samping pada manusia. ${ }^{2}$ Penelitian Adam dkk, menunjukan bahwa daun kelor dapat dijadikan sebagai co-chemotherapy doksorubisin karena mengandung phenethyl isothiocyanate (PEITC) dan benzyl isothiocyanate (BITC). ${ }^{4}$ Penelitian lain menyatakan bahwa ekstrak air ${ }^{5,6}$, hidroalkohol dan alkohol ${ }^{7}$ dari daun kelor menunjukkan adanya aktivitas sitotoksik, analgesik, anti radang, anti hipertensi, radioprotektif dan imunomodulator. Aktivitas sitotoksik dikarenakan daun kelor tersebut banyak mengandung flavonoid. Flavonoid seperti kuersetin, kaempferol dan myricetin merupakan kandungan yang terbanyak pada daun kelor. ${ }^{2,5}$

\section{Morfologi dan Klasifikasi Daun Kelor (Moringa oleifera L.)}

Kelor merupakan tanaman dalam famili Moringaceae, yang tumbuh di daerah tropis dan subtropis, banyak tersebar di Asia Tenggara, seperti Vietnam, Sri Lanka, India, Malaysia, Thailand dan Indonesia. Tanaman ini sudah sejak lama dimanfaatkan sebagai bahan makanan ternak, makanan tradisional, serta sebagai bahan obat-obatan tradisional. ${ }^{8}$ Semua bagian tanaman kelor secara tradisional digunakan untuk tujuan yang berbeda, tetapi yang paling sering digunakan adalah daun. ${ }^{4}$ Daun kelor kaya akan senyawa protein, mineral, beta-karoten dan antioksidan; senyawa-senyawa tersebut merupakan senyawa yang bermanfaat namun belum banyak diteliti dan dimanfaatkan secara maksimal pada populasi negara terbelakang atau 


\section{Review Article}

berkembang. $^{8}$

Tanaman kelor memiliki akar tunggang, berwarna putih, biasanya bercabang atau serabut dan dapat mencapai kedalaman 5-10 meter. Akar ini berguna untuk membantu penyerapan air dalam tanah, serta membantu sebagai penyokong pertumbuhan tanaman kelor. Batang tanaman ini dapat tumbuh mencapai 12 meter, batang tidak terlalu keras, berkulit tipis, permukaan kasar, banyak percabangan dan arah percabangan cenderung tegak atau agak miring dengan pertumbuhan lurus dan memanjang. ${ }^{2}$ Daun kelor berbentuk bulat telur, dengan ukuran relatif kecil, daun majemuk, tersusun selang seling, beranak daun gasal, helai daun berwarna hijau muda dan biasanya digunakan sebagai obat tradisional. Bunga kelor berwarna putih kekuningkuningan dan memiliki pelepah bunga berwarna hijau. Buah kelor berbentuk segitiga memanjang berkisar antara $20 \mathrm{~cm}$ hingga $60 \mathrm{~cm}$, sering disebut juga sebagai kelentang dan berwarna hijau muda hingga kecoklatan. Biji kelor berbentuk bulat dan berwarna coklat kehitaman. Dalam satu biji ini akan terdapat beberapa (10 sampai dengan 20 biji) butir dalam buah. $^{2}$

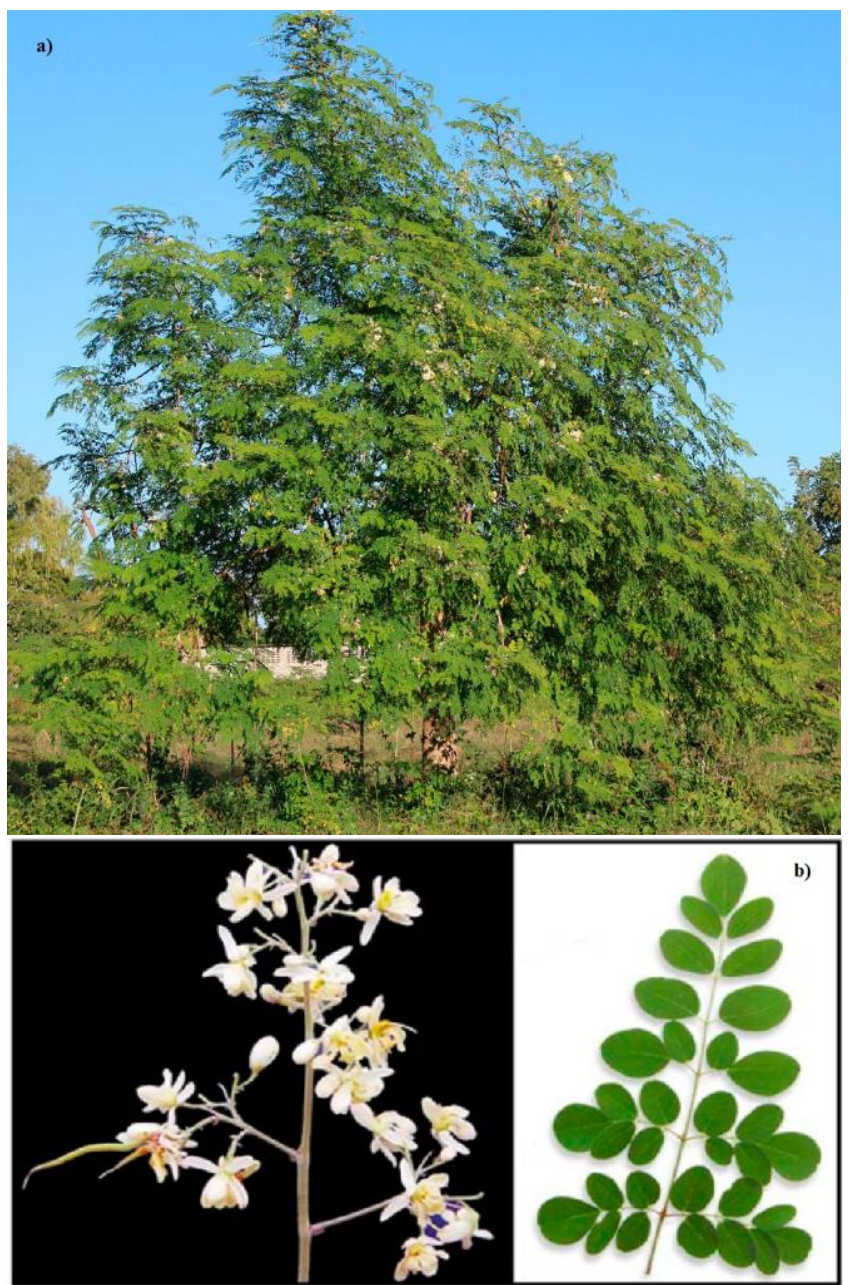

Gambar 1(A) Tanaman kelor (B) Bunga dan daun kelor Dikutip dari Leone A, et $a l^{2}$ 
Menurut klasifikasi Cronquist (1981), daun kelor dapat diklasifikasikan sebagai berikut:

$\begin{array}{ll}\text { Kingdom } & \text { : Plantae (Tumbuhan) } \\ \text { Subkingdom } & : \text { Tracheobionta (Tumbuhan berpembuluh) } \\ \text { Super Divisi } & : \text { Spermatophyta (Menghasilkan biji) } \\ \text { Divisi } & \text { : Magnoliophyta (Tumbuhan berbunga) } \\ \text { Kelas } & : \text { Magnoliopsida (berkeping dua / dikotil) } \\ \text { Sub Kelas } & : \text { Dilleniidae } \\ \text { Ordo } & : \text { Capparales } \\ \text { Famili } & : \text { Moringaceae } \\ \text { Genus } & : \text { Moringa } \\ \text { Spesies } & : \text { Moringa oleifera Lam }\end{array}$

\section{Fitokimia Daun Kelor (Moringa oleifera L) yang Memiliki Efek Antikanker}

Daun kelor (Moringa oleifera) mengandung beberapa senyawa kimia dalam bentuk beberapa senyawa bioaktif yaitu vitamin, karotenoid, polifenol, asam fenolik, flavonoid, alkaloid, glucosinolat, isothiocyanat, tanin, saponin dan oksalat. Ekstrak dari tanaman daun kelor ini sudah terbukti memiliki beberapa khasiat untuk kesehatan, yakni sebagai antiinflamasi, anti-oksidasi, anti-mikroba, antivirus, antitumor, antiaterosklerosis, hipoglikemik, dan antikanker. Senyawa yang memiliki efek antikanker tersebut diduga berasal dari golongan flavonoid. Komponen flavonoid, diantaranya kuersetin, kaempferol dan myricetin. ${ }^{2}$<smiles>O=c1c(O)c(-c2ccc(O)c(O)c2)oc2cc(O)cc(O)c12</smiles>

Gambar 2 Rumus kimia kuersetin ${ }^{2}$ 
<smiles>O=c1c(O)c(-c2cc(O)c(O)c(O)c2)oc2cc(O)cc(O)c12</smiles><smiles>O=c1c(O)c(-c2ccc(O)cc2)oc2cc(O)cc(O)c12</smiles>

\section{Gambar 4 Rumus kimia kaempferol ${ }^{2}$}

Flavonoid merupakan senyawa polifenol yang dihasilkan dari metabolisme sekunder pada tanaman. Flavonoid tersusun atas 15 atom karbon yang memiliki 2 cincin benzen (cincin benzen A dan B) yang keduanya terhubung melalui cincin piran heterosiklik (cincin C). ${ }^{9}$ Flavonoid dapat dibagi menjadi beberapa kelas, diantaranya flavon (seperti flavone, apigenin, dan luteolin), flavonols (seperti kuersetin, kaempferol, myricetin, dan fisetin), flavanon (seperti flavanon, hesperetin, dan naringenin), dan beberapa kelas lainnya. Kelas flavonoid antara satu dan yang lain memiliki perbedaan pada tingkat oksidasi dan pola substitusi dari cincin C. Pada masing-masing jenis senyawa individu pada setiap kelas flavonoid juga terdapat perbedaan pola substitusi pada cincin A dan B. ${ }^{9}$

\section{Efek Antikanker Kuersetin, Kaempferol dan Myricetin secara Molecular}

Kuersetin merupakan molekul flavanol yang terdapat pada daun kelor (Moringa oleifera L.). Kuersetin memiliki aktivitas antioksidan yang dimungkinkan oleh komponen fenoliknya yang sangat reaktif. ${ }^{10}$ Kuersetin akan mengikat spesies radikal bebas sehingga dapat mengurangi reaktivitas radikal bebas tersebut. Molekul flavanol merupakan salah satu jenis flavonoid yang aktif sebagai antioksidan. ${ }^{11}$ Senyawa karsinogen merupakan senyawa yang mampu mengoksidasi DNA sehingga terjadi mutasi. Kuersetin sebagai antioksidan dapat mencegah 


\section{Review Article}

terjadinya oksidasi melalui dua fase. Pada fase pertama, kuersetin mampu menstabilkan radikal bebas yang dibentuk oleh senyawa karsinogen seperti radikal oksigen, peroksida dan superoksida. Kuersetin menstabilkan senyawa-senyawa tersebut melalui reaksi hidrogenasi maupun pembentukan kompleks. ${ }^{11}$ Melalui reaksi tersebut radikal bebas diubah menjadi bentuk yang lebih stabil sehingga tidak mampu mengoksidasi DNA. Selain itu, didapatkan turunan radikal antioksidan yang relatif memiliki keadaan yang lebih stabil dibandingkan radikal bebas yang dibentuk senyawa karsinogen tadi. Meskipun demikian radikal kuersetin memiliki energi untuk bereaksi dengan radikal antioksidan lain. Radikal-radikal antioksidan dari kuersetin dapat saling bereaksi membentuk produk nonradikal. ${ }^{9}$ Pada fase lainnya, kuersetin mencegah autooksidasi, yaitu mencegah pembentukan radikal peroksida melalui pengikatan senyawa radikal secara cepat agar tidak berikatan dengan oksigen. Dengan adanya kuersetin maka reaksi oksigenasi yang berjalan secara cepat dapat di cegah sehingga pembentukan radikal peroksida pun dapat dicegah. Kuersetin juga berikatan dengan radikal peroksida yang telah terbentuk dan menstabilkannya sehingga reaksi autooksidasi yang secara cepat dan berantai dapat dihambat. ${ }^{12}$

Kuersetin dapat juga menginduksi apoptosis melalui jalur intrinsik dengan cara menginhibisi mitogen-activated protein kinase (MAPK), extracellular-signal-regulated kinase 1/2 (ERK 1/2), c-Jun N-terminal protein kinase 1 (JNK), dan protein kinase C (PKC). ${ }^{12,13}$ MAPK pathway merupakan jalur yang penting dalam pengaturan ekspresi gen pada sel eukariotik dan dapat menyebabkan berbagai respon biologi seperti pertumbuhan sel, proliferasi, diferensiasi, migrasi dan apoptosis. Ketika jalur MAPK dihambat, akan mengakibatkan peningkatan Bax pada mitokondria, dan penurunan Bcl-2. Peningkatan Bax tersebut akan membuat pore pada mitokondria sehingga sitokrom c keluar melalui pore tersebut. Sitokrom c kemudian berikatan dengan apaf-1 yang akan mengaktifkan caspase 9, kemudian caspase 9 akan mengaktifkan caspase 3 yang pada akhirnya akan menyebabkan apoptosis. ${ }^{10,13}$

Selain itu kuersetin juga berperan dalam menekan ekspresi mutan protein p53. Pada kondisi wild type, protein ini merupakan protein yang penting dalam kontrol siklus sel, yaitu dengan memacu sel untuk berhenti (arrested) atau apoptosis. Namun apabila terjadi mutasi maka protein ini menjadi sebuah penanda abnormalitas yaitu siklus memacu sel ke fase G2/M (penggandaan sel) dan apabila sel terus menerus pada fase ini maka akan terjadi proliferasi (pembelahan tak terkendali). Kuersetin dalam konsentrasi serum $248 \mu \mathrm{M}$ dapat menekan ekspresi dari mutan protein p53 yang dibentuk oleh sel kanker payudara sampai tidak terdeteksi pada sel tersebut. ${ }^{11}$

Kaempferol dan myricetin merupakan senyawa antikanker dan antioksidan yang banyak ditemukan dalam buah-buahan dan daun-daunan, salah satunya daun kelor. Kaempferol dan myricetin dapat mengurangi risiko penyakit kronis, terutama kanker. Studi epidemiologis 


\section{Review Article}

menunjukkan hubungan terbalik antara asupan kaempferol dan kanker. Kaempferol dapat menambah antioksidan tubuh yang merupakan pertahanan terhadap radikal bebas. Pada tingkat molekuler, kaempferol telah dilaporkan untuk memodulasi sejumlah elemen kunci dalam transduksi sinyal seluler jalur terkait dengan apoptosis, angiogenesis, peradangan, dan metastasis. Kaempferol dan myricetin menghambat sinyal transduksi, seperti protein tyrosine kinase (PTK), protein kinase $C$ (PKC) dan phosphoinositide 3 kinase (PIP). Flavonoid juga menyebabkan penghambatan siklus sel pada fase G1dan G2 lewat penghambatan CDK (Cyclin D Kinase). CDK telah diketahui sebagai regulator perkembangan siklus sel. Perubahan dan disregulasi dari aktivitas CDK merupakan suatu tanda dari keganasan. Beberapa kanker berhubungan dengan aktivasi dari CDK sebagai hasil mutasi dari gen CDK atau gen CDK inhibitor. Check point pada siklus sel fase G1/S dan fase G2/M dapat dihambat oleh kaempferol. Secara signifikan, efektifitas kaempferol dapat menghambat pertumbuhan sel kanker, angiogenesis dan menginduksi apoptosis sel kanker, tetapi dapat juga menjaga kelangsungan hidup sel normal. ${ }^{14}$

Fosforilasi $\mathrm{Bcl} 2$ akan mengakibatkan stabilnya ikatan antara Bcl2-Bax, menghambat degradasi Bcl2 dan memblokade ikatan dengan p53 sehingga menyebabkan sel mengalami anti apoptosis. ${ }^{15}$ Beberapa protein kinase yang dapat membantu fosforilasi Bcl2 adalah MAPK (mitogen-activated protein kinase), ERK1/2 (extracellular-signal-regulated kinase 1/2), JNK1 (c-Jun N-terminal protein kinase 1) dan PKC (protein kinase $C$ ). Beberapa flavonoid yang dapat menurunkan MAPK, ERK, JNK dan PKC adalah kuersetin, kaempferol dan myricetin. ${ }^{15}$

\section{Simpulan}

Zat-zat aktif anti kanker pada daun kelor (Moringa oleifera L.) yaitu kuersetin, kaempferol dan myricetin, dapat menginduksi apoptosis melalui jalur intrinsik dengan cara inhibisi mitogen-activated protein kinase (MAPK), extracellular-signal-regulated kinase 1/2 (ERK 1/2), c-Jun N-terminal protein kinase 1 (JNK), dan protein kinase C (PKC).

\section{Daftar Pustaka}

1. Kementrian Kesehatan RI. Pusat Data dan Informasi [database on the Internet]. 2013 [cited 2016 Nov 22]; Available from: http://www.depkes.go.id/resources/download/pusdatin/infodatin/infodatin-kanker.pdf

2. Leone A, Spada A, Battezzati A, Schiraldi A, Aristil J, Bertoli S. Cultivation, genetic, ethnopharmacology, phytochemistry and pharmacology of Moringa oleifera leaves. An overview. Int J Mol Sci. 2015; 16(6): 12791-835.

3. Tewari K, Sill M, Long H, Penson R, Huang H, Ramondetta L, et al. Improved survival with bevacizumab in advanced cervical cancer. N Engl J Med. 2014; 370(8): 734-43.

4. Hermawan A, Nur K, Dewi D, Putri P, Meiyanto E. Ethanolic extract of Moringa oleifera increased cytotoxic effect of doxorubicin on HeLa cancer cells. JNR. 2012; 12(2): 108-14.

5. Sreelatha S, Jeyachitra A, Padma P. Antiproliferation and induction of apoptosis by Moringa oleifera leaf extract on human cancer cells. FCT. 2011; 49(6): 1270-5. 


\section{Review Article}

6. Chumark P, Khunawat P, Sanvarinda Y, Phornchirasilp S, Morales N, Phivthong-ngam L, et al. The in vitro and ex vivo antioxidant properties, hypolipidaemic and antiatherosclerotic activities of water extract of Moringa oleifera Lam. leaves. J Ethnopharmacol. 2008; 116(3)1-8.

7. Banji O, Banji D, Kavitha R. Immunomodulatory effects of alcbholic and hydroalcoholic extracts of Moringa olifera Lam leaves. Indian J Exp Biol. 2012; 50(4): 270-6.

8. Stohs S, Hartman M. Review of the safety and efficacy of Moringa oleifera. Phytother Res. 2015; 29(6): 796804.

9. Majewska-Wierzbicka M, Czeczot H. Anticancer activity of flavonoids. Pol Merkur Lekarski. 2012; 33(1):3649.

10. Vargas AJ, Burd R. Hormesis and synergy: pathways and mechanisms of quercetin in cancer prevention and management. Nutr Rev. 2010; 68(7):418-28.

11. Duo J, Ying G, Wang G, Zhang L. Quercetin inhibits human breast cancer cell proliferation and induces apoptosis via Bcl-2 and Bax regulation. Molecular Medicine Reports. 2012; 5(6): 1453-6.

12. Kim M, Lee H, Lim B, Ha K, Kim S, So I, et al. Quercetin induces apoptosis by inhibiting MAPKs and TRPM7 channels in AGS cells. Int J Mol Med. 2014; 33(1): 1657-63.

13. Qingcin L, Xianggui C, Guolin Y, Xuewen M, Maoxian D. Apigenin inhibits cell migration through MAPK pathways in human bladder smooth muscle cells. Biocell. 2011; 35(3): 71-9.

14. Chen A, Chen Y. A review of the dietary flavonoid, kaempferol on human health and cancer chemoprevention. Food Chem. 2013; 138(4): 2099-107.

15. Shaun W, Simon D. Post-transcriptional and post-translational regulation of Bcl2. Biochem Soc Trans. 2010; 38(6): 1571-5. 